Y. A. Battal Saleh

\title{
Economic crimes in Libya: the phenomenon of illegal earning and money laundering before and after the February 17, 2011 revolution
}

\section{KEYWORDS \\ illegal earning; \\ money laundering (corruption); \\ dictatorship;}

government policy and regulation;

revolution;

economic development;

economic decline;

public policy

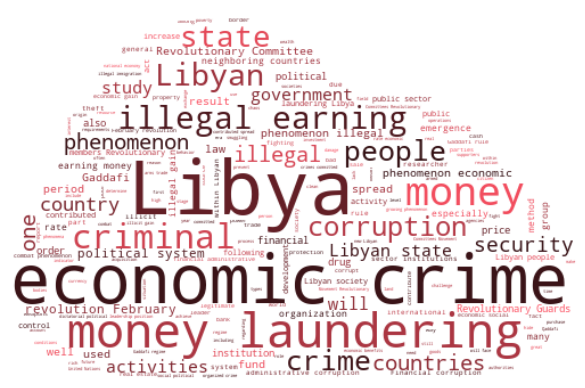

Word Cloud Generated by:

https://wordscloud.pythonanywhere.com/

\section{ABSTRACT}

Economic crimes in Libya have become a source of concern for all honorable Libyans who aspire to build their desired state. Economic crime was and remains the foremost enemy of economic development in this afflicted country. And as a first step to learn how to combat this bad phenomenon, this study identified methods of illegal gain before and after the February 17, 2011 revolution in Libya, with reference to the role of the political system in the growth of this phenomenon. In Libya, for the nonpolitical and non-leadership figures, in the absence of the institutions of the modern state, with a noticeable weakness in regulatory regimes and security bodies, once the illegal money is acquired (illegally acquired funds) without the presence of criminal evidence can be used to convict or accuse someone, whereupon, the money will be clean and washed, no need for the process of washing. This situation is continued until after the revolution of February 17, 2011. Dictatorial Political system in Libya was one of the difficulties that prevented the process of money laundering fighting and the illegal gain. Dictatorial Political system in Libya was turning a blind eye to criminal activities associated with the illegal gain and money laundering which was executed by Members of the Revolutionary Committees and the Revolutionary Guards in return for (in exchange for) providing the protection to this system in order to stay in power as long as possible. The spread of poverty among the sons of Libyan people contributed to the growing of the illegal gain phenomenon and money laundering. The lack of effective oversight bodies and security agencies has also contributed to the growth of all negative phenomena within Libyan society. When the Libyan revolution occurred in 2011 and in the shadow of overwhelming chaos - it is still going on, many criminals and prisoners "who emerged from prisons during that period" made huge fortunes in illegal ways. These people will become businessmen in the future. What is expected of this group of people will be disastrous. The expected thing about this group of criminals is that they will not be lambs, they will be predatory wolves. Based on this expectation, the level of economic crimes and corruption in the Libyan state will increase in the future. There are some difficulties that will face the new Libyan government to fight of money laundering phenomenon and the illegal gain. The new Libyan government will face many challenges when it begins to combat economic crime phenomenon, that challenges are the spread of weapons and the vast geographical boundaries. Proliferation of arms in the hands of the people is the most important challenge that will hinder the process of combating money laundering and illegal earning activities. The lack of possibilities to guard the geographical boundaries of Libya to prevent illegal immigration and smuggling of goods, fuel and drugs. It is also another challenge. As a radical solution to this negative phenomenon, this study suggested the optimal methods to combat the phenomenon of illegal earning and money laundering in Libya.

Battal Saleh, Y. A. (2020). Economic crimes in Libya: the phenomenon of illegal earning and money laundering before and after the February 17, 2011 revolution. Economic consultant, 31 (3), 53-80. doi: 10.46224/ecoc.2020.3.4 


\section{THE NEW IDEA IN THIS STUDY}

\section{The requirements for the continuation of a dictatorial political rule}

In the world of politics, a dictatorial regime can remain in power as long as possible if that regime adheres to the necessary survival requirements. It is these requirements that Qaddafi was committed to in order to remain for more than 42 years a ruler of Libya. From the historical reality of the era of Gaddafi rule, this study concluded the following truth: There are four main requirements that contribute to the survival of any illegitimate "dictatorial" political system in government "as a ruling authority" as long as possible, those requirements are: Complete domination over the state's wealth "the impoverishment of the people to make their thinking not exceed their daily food"; Tightening the security grip managed by the regime's supporters; Turning a blind eye to the crimes committed by the supporters of this regime, including economic crimes, as an incentive and a legitimate right for them in exchange for protecting that system; Weakening the role of anti-economic crime bodies "anti-corruption organizations and other illegal earning crimes". It is these requirements that contributed to Gaddafi remaining for more than 42 years as president of Libya.

\section{Predicting the future of corruption in Libya}

The Illegal "dictatorial" political systems often need protection from their supporters to stay as a ruling authority in the state for the longest possible period, and the price that should be offered by those illegal political regimes is to turn a blind eye to the economic crimes committed by their supporters. The illegal political system often contributes to spreading poverty within society so that it can be easily controlled. In such societies, economic crimes spreads at a higher rate than democratic societies. This is what happened in Libya and is still happening. After the revolution of February 17, 2011 in Libya, and in the absence of state institutions, the rate of economic crimes rose dramatically. As well as, from 2011 to 2020 , criminals managed to accumulate vast fortunes from illegal actions. This may indicate a possible increase in the level of corruption in Libya in the future, due to the possible emergence of the corrupt businessmen group. Those criminals are likely to be businessmen in Libya in the future. Accordingly, the researcher expects to increase the rate of economic crime in Libya. Illegal money owned by criminals, the result will be a rise in the rate of economic crimes in Libya. To counter this danger, as a radical solution, this study suggested the optimal methods to combat the phenomenon of illegal earning and money laundering in Libya.

\section{INTRODUCTION}

The annual reports issued by Transparency International show that the phenomenon of financial and administrative corruption in Libya is taking a dangerous escalation, until the 
country has become within the constellation of countries that have been destroyed by this phenomenon in light of the state of security chaos and the absence of a central authority that imposes control over the management of public money and the wealth of the country in an efficient manner that guarantees its protection from theft, embezzlement and waste. The period of the Gaddafi regime's rule was not without the excesses of those with military, political and administrative influence, as in 2010 Libya ranked 146th out of 180 countries in the corruption index according to the report of Transparency International, but these abuses were neither systematic nor structural under the institutions of a stable state. They were reflecting some kind of exploitation by some officials of their power and influence, but after the fall of the regime the phenomenon of corruption exploded just as the political and security conditions also worsened, turning economic crime into a systematic and structural phenomenon that plagues various sectors and institutions so that Libya ranks 171st globally in the corruption indicators in 2018 according to the report of the same organization. Reading the results of Transparency International's reports on corruption in Libya seems to be of great importance, which helps to understand the developments that the phenomenon has witnessed during the past eight years. It is a phenomenon that is greatly exacerbated in the countries of the so-called Arab Spring, including Tunisia, which ranks 74th in the world. The general and escalating pattern that the phenomenon of corruption in Libya has taken not only indicates the extent of its exacerbation, but also indicates its coincidence with the disintegration of state institutions and regulatory agencies and even the disintegration of the national political culture system that is victorious to protect public money from any form of abuse or tampering with it. During the year 2010, Libya maintained the 146th rank in the perceptions of financial and administrative corruption before the armed groups shared the country's geopolitical map, but with the spread of the state of arms chaos, it fell to the 168th place and then climbed to the 172nd place in 2013, and during the years 2014 and 2015 the rank ranged between 166 and 161 And, since 2016, Libya seemed to be plunged into a quagmire of corruption, as the corruption index rose from 170th to 172 nd in 2017, reaching its peak in 2018, as Libya ranks 171 st and is classified by Transparency International as one of the countries destroyed by corruption. The revolutionaries have taken advantage of public money and Libyan wealth since 2011 to provide as much weapons as possible, buy people off with money, and bullying with money in order to extend their influence and control even though even though they were proclaiming that they were missionaries for new clean, transparent and democratic Libya, and the situation is that they have practically thrown it into various forms of financial and administrative corruption, in a state of underestimation that does not stop tampering with the livelihood and sustenance of Libyans [24].

Financial corruption is one of the types of illegal earning. Financial corruption is related to illegal behavior in government institutions "public sector institutions". It means exploiting the public office to achieve personal economic gains that are not permitted by law. Illegal earning and money laundering are economic crimes. Illicit gain "Illegal earning" includes all activities through which money and economic benefits can be unlawfully acquired. While 
money laundering aims to hide the illegal source of dirty money production, mislead the state's security and regulatory bodies and make dirty money as if it is legitimate money. "Illegal earning" or economic crime in general "threatens the integrity of markets, weakens fair competition", it does not achieve social justice among the people with regard to the equitable distribution of economic resources, "damage public trust; undermine the rule of law and also its impact on the development of the economy as a whole" $[16 ; 22 ; 29]$.

The Libyan state suffers from the phenomenon of illegal earning, "economic crime" for many years. This phenomenon contributed directly to obstructing real economic development and the spread of many social diseases within Libyan society. Several factors contributed to the spread of this phenomenon, but the political system "during Gaddafi's rule" contributed directly to the spread of this phenomenon over the entire Libyan soil. This phenomenon increased sharply after the end of Gaddafi's rule, due to the lack of effective institutions "regulatory bodies and security agencies" within the Libyan state that could contribute to fighting this bad phenomenon radically. In this study, the researcher will present a statement about this phenomenon before and after the February 17, 2011 revolution, in addition to proposing a package of solutions and proposals to combat it.

\section{LITERATURE REVIEW}

The frightening increase in indicators of economic crimes and the growing phenomenon of corruption in the Libyan state indicates an unprecedented catastrophic situation in the Libyan state. This tragic situation is no longer a secret, everyone knows this fact, whether inside or outside Libya. Most of the local and international media, reports of the United Nations and organizations concerned with economic crimes and corruption have expressed their concern about the disastrous situations related to the growing phenomenon of economic crimes in Libya "high indicators of economic crime in Libya", in the years following the February 2011 revolution. In the modern era, Libya has come to be referred to as a failed state despite its enormous economic potential. This bad phenomenon that swept Libya needs a radical and scientific treatment. To achieve this, it is necessary to diagnose" understand" this phenomenon, track its historical growth in Libya, and determine its causes, motives, and ways to combat it. Anyone who follows the history of economic crime in Libya - during the twentieth century and the beginning of the twenty-first century will notice that there has been a significant change in its types, methods, requirements, and motives. The development of economic crime during this period of time was largely linked to the political, economic and social changes, "the change in the demography of the Libyan people/the dynasties and ethnicities that makes up the Libyan society" that occurred in the Libyan state. In other words, there are many political, economic and social factors that helped the development and diversity of economic crimes in Libya. By relying on the accounts of grandparents and the elderly "older persons", the information recorded in the records of the judicial and security bodies and the reports of 
the United Nations and Transparency International, it is possible to describe the nature of economic crimes and the paths of their historical development on the Libyan arena during the period from the beginning of the twentieth century to the present time, which can be divided to four time periods as follows: 1) The period before independence and before the rule of King Idris Al-Senussi, "The period of jihad against the Italian invasion of Libya". Libyan society is a tribal society governed by a set of noble customs and traditions, and the teachings of the Islamic religion - that incite the non-commission of crimes of all kinds and types, which cannot be violated in any way. Each tribe inhabited a specific geographical area in Libya, and this matter contributed to controlling security matters within those areas. The Libyan people were preoccupied with jihad and the struggle against the Italian invasion in that era. Committing crimes such as theft is a great shame and a shameful act that harms the reputation of the family and the tribe. In the first half of the twentieth century, and before the emergence of oil, the Libyan economy was mainly dependent on agriculture, livestock and trade with neighboring countries. There were no indications of the existence of a civil state in Libya at that time. Financial and administrative corruption did not exist at that period due to the absence of institutions in the Libyan state. The economic crime that was prevalent in that period is theft of others' property. It is rare and its motivation is poverty and hunger. It was represented in the theft of agricultural crops and livestock "such as sheep, cows, goats and camels" from open pastures or closed barns, as well as stealing jewelry from primitive homes "tents and houses built of mud and stones, which lack the protection systems that exist today"; 2) The period of the reign of King Idris Al-Senussi "independence of Libya, building the Libyan state, and the emergence of oil". After Libya gained its independence and King Idris Al-Senussi took over the reins of government in Libya and the emergence of oil as an economic resource in Libya, the features of the Libyan state began to appear. King Idris Al-Senussi was interested in building the Libyan state institutions in all sectors. What distinguishes this period is the return of the Libyan immigrants to the homeland, as well as the acceptance of applications for Libyan nationality submitted by citizens of neighboring countries such as Tunisia, Egypt, Morocco, Algeria, Chad and Sudan, etc. This change in the demography of the Libyan state had negative effects on Libyan society. The returning Libyans and the Arab and African brothers who became citizens by rule of law brought with them the cultures and customs of other peoples, especially bad habits and behaviors such as bribery, embezzlement, forgery and so on, to be part of the bad cultures and practices in the future of Libyan society. Economic crimes were confined to the theft of private and public property, but at natural rates. The beginning of the emergence of financial and administrative corruption in the institutions of the Libyan state - which was practiced by government employees and members of the ruling class, was during this period. The indicators of corruption were not as frightening as they were during the Gaddafi era and after his rule. Indicators of corruption were natural "low" that could be found in any country. The rate of economic crime was not as great as it is now due to the presence of a strong security grip in addition to the presence of the noble norms and traditions and the teachings of the Islamic religion that control the behavior of most Libyans to be on the right path; 3) The 
period of Gaddafi's rule, "the period of dictatorial rule and the acquisition of/ taking control of the wealth of the Libyan people. Gaddafi acquired "took over" the wealth of the Libyan people by force. Gaddafi, during his rule of Libya, pursued a systematic policy aimed at impoverishing the Libyan people- in order to facilitate effective control over them by controlling their daily sustenance, also, Gaddafi planted all social ills within this clean society. With the increase in the cost of living and the state of poverty that included all Libyans, the phenomenon of economic crime and illegal earning has grown. During Gaddafi's rule, financial and administrative corruption spread on a large scale within state institutions and the motives were either due to meeting the requirements of daily living or Because of affluence and a luxurious life. In that period of time, the Libyan people were described as the poor people who live in a country rich in natural resources. A culture of corruption has spread within Libyan society. Indicators of economic crime increased in the Libyan state, making Libya one of the most corrupt countries in the world. Most of the supporters of the Gaddafi regime became rich after they were poor. They are always above the law; 4) Post-Gaddafi period "the collapse of the dictatorship". After the Gaddafi regime was toppled in 2011, after the Gaddafi regime was toppled in 2011, state institutions collapsed, especially the security and judicial institutions, to be replaced by the language of bullying and the rule of jungle law. During this period the wealth of the Libyan people was systematically plundered. Armed militias and new corrupt politicians appeared and began plundering the wealth of the Libyan state. New economic crimes have appeared that did not exist before, and the crime rate has doubled horribly in Libya. Economic crimes have directly contributed to the deterioration of the economic situation in Libya and have become a source of concern for all Libyans who are loyal to their country and those interested in Libyan affairs. The rate of economic crime has reached its peak in a catastrophic outrageous situation, according to reports of local and international organization.

Economic Crime is an increasing source of concern in the international arena. Economic crime "illegal earning" is a global phenomenon that exists in almost all countries, but at varying rates. It is one of the bad phenomena, that all countries seek to combat it with all available means. It will be necessary to differentiate among the following concepts: Economic Crime "Illegal Earning"; Financial Corruption; Money Laundering; Organized Crime. In order to remove any ambiguity around these concepts. Economic crime includes all illegal activities with the aim of achieving illegal economic gains. Financial corruption is one of the economic crime activities. Money laundering is to dismiss suspicions about illegal money "to shifted suspicion away from illegal money". Organized Crime is a group of professional criminals who work together as part of a powerful and secret organization.

Economic crime has evolved through the ages with the development of economic, social, cultural and political life in societies. As the methods and tools used to achieve illegal earning have evolved. Economic crime has evolved from the simple level "theft of others' property" to the complex level, or what is known as organized crime "a group of professional criminals who work together as part of a powerful and secret organization" (Merriam-Webster, n.d.). Organized crime is the crime that is carried out by a group of criminals- who have one common 
interest "illegal earning", in a more organized way. In the modern era, economic crimes affect the national economy and the social and political life of the countries where these crimes are committed. For this reason, states work hard and non-stop to combat the phenomenon of illegal earning in all ways and methods, including the use of excessive force in most cases, in order to avoid the negative effects produced by those illegal activities. In fact, economic crimes are more prevalent in developing countries and poor societies than in developed countries and rich societies.

The concept of financial corruption and the concept of economic crime are often confused. Financial corruption is one of the types of economic crimes "illegal gain". Financial corruption is "generally speaking as" the abuse of entrusted power for private economic gain, while economic crimes include all activities and acts that are not permitted by law in a country in order to achieve economic gains. This is the subject of research in this study.

Definition of economic crime. Economic crime, also known as financial crime, refers to illegal acts committed by an individual or a group of individuals to obtain a financial or professional advantage. The principal motive in such crimes is economic gain (Europol, n.d.). Financial crime is defined as crime that is specifically committed against property. These crimes are almost always committed for the personal benefit of the criminal, and they involve an illegal conversion of ownership of the property that is involved. Financial crimes can occur in many different forms, and they happen all over the world. Some of the most common crimes facing the financial sector are money laundering, terrorist financing, fraud, tax evasion, embezzlement, forgery, counterfeiting, and identity theft. These crimes are committed every single day, and governments across the globe are constantly prosecuting financial criminals while searching for new ones (Complyadvantage, N.D.). The researcher defines economic crime as follows: The term "economic crime" refers to all acts and activities that are not permitted by law in a country, and that result in economic gains "money or economic benefits" for a person or group of people, or mutual economic benefits among the parties to that criminal activity, or causing damage to one of the parties "parties of criminal activity", the end result of those acts and activities is to create economic and social problems within society in general in that country.

\section{Conditions that must be satisfied in any activity or act in order to be classified as an economic crime}

An act or activity not permitted by law in a country because of its economic, social, political, and health damage; That action or activity results in achieving economic gains for one or all of the parties implementing that act or activity, but mostly there are affected people; The contribution of the act or activity in weakening the national economy of the state and the negative impact on social and political life within that state.

\section{Illegal earning (illicit gain)}

An illicit activity or substance is not allowed by law or the social customs of a country

"results in economic gains" (Reverso Dictionary). The researcher defines the phenomenon of 
illicit gain as follows: It is a phenomenon that spreads in developing countries at a greater rate than developed countries and in poor societies with a greater rate than rich societies. It is the acquisition of money "movable or immovable property" or other economic benefits resulting from activities that are not permitted by law in a country or by circumventing the laws in force in that country.

\section{Financial corruption "Bribery and Embezzlement of funds of public sector institutions"}

Recently the corruption is one of the biggest issues around the world. The corruption is closely linked with the governments' behavior and their activities and also with some of the government affairs in the economy. It is a hazard facing society and exits both in the developing and also the developed economies but more witness in the developing nations. Therefore, it is an indicator of a poorly functioning nation. The World Bank defines the corruption as 'the abuse of public power for private benefit". It does not mean that corruption is limited to only the public sector. It can be seen especially in large private enterprises also [29, p. 36].

Corruption is divided into two types: administrative corruption and financial corruption. Administrative corruption is the misuse of the power of a government job by a government employee in illegal and immoral practices, behaviors, and acts such as nepotism, favoritism, persecution, and sexual harassment. These practices and behaviors mean granting certain rights and privileges to people who do not deserve them. These behaviors primarily affect social justice within the community and public job ethics. Financial corruption is the misuse of the power of a government job by a government employee in illegal activities for financial gain or economic benefits for that government employee or any of his/her relatives or friends, such as bribery and embezzlement. It should be noted that, according to Transparency Organization reports, Libya is ranked among the most corrupt countries in the world.

\section{Money laundering}

Money laundering can be defined as: combining the funds resulting from illegal trafficking, especially from drugs and arms trade, with other clean money used in legitimate investments, which in turn leads to the difficulty of monitoring and sorting them out with the knowledge of the legal and regulatory agencies. It is worth noting that there is a difference between dirty money and black money, the first is the money that criminals want to clean them up, which mainly results from illegal activities, and whose owners prefer to pay taxes on them to give them some kind of legitimacy. The second is that which is kept strictly confidential "hoarded and hidden" in order to evade taxes [2, p. 15].

The crime of money laundering is one of the most important economic crimes in the modern era, that is often associated with organized crime, especially, crimes of terrorism and smuggling of arms and drugs, gambling, robbery and kidnapping and political corruption, etc. Phenomenon of money laundering is one of the dangerous phenomena that faces many countries of the world because of its dangerous economic effects, and social and political problems on the state and its position in the international community. That ease of transmission 
the money across different countries in light of liberalization of international trade was one of the factors that helped to spread the phenomenon of money laundering, as the movement of money circulation of criminal organizations at the local level and international was increased significantly, in order to hide (secretion or concealment) the legitimacy of that money gained illegally to look as if it's clean money.

\section{Where did the term' money laundering' come from?}

The term money laundering is said to have its origins from the mafia's ownership of Laundromats in the US in the 1920's and 1930's. "Italian members of the mafia in the U.S., such as Al Capone". Organized criminals were making so much money from extortion, prostitution, gambling and bootlegging, they needed to show a legitimate source of the money. One way in which they could do this was to purchase outwardly legitimate businesses and to mix their illicit earnings with the legitimate earnings from these businesses. Laundromats were chosen because they were cash businesses. Al Capone used this method in Chicago. Journalist Geoffrey Robinson regards the tale that money laundering came from this as a myth. He states: Money Laundering is called what it is because it perfectly describes what takes place - illegal or dirty money is put through a cycle of transactions, or washed, so that it comes out the other end as legal or clean money. In other words, the source of the illegally obtained funds is obscured through a succession of transfers and deals in order that those same funds can eventually be made to appear as legitimate income [15]. Nevertheless, the earliest reported use of the term 'money laundering' in a legal context was in the US in 1982, in the case of US v $\$ 4,225,625.39$ [14]); and it was not until 1986 that money laundering became a criminal offence. The United States was the first country in the world to criminalize ML, through the Money Laundering Control Act 1986. (This Act was a direct response to the case US v. Anzalone (1985) US 766, F.2d 676 1st Cir.) The second country was the UK, through the Drug Trafficking Offences Act 1986 that criminalized the proceeds of drug trafficking activities (Drug Trafficking Offences Act 1986, article 24.).

It is necessary now to analyze the phenomenon of ML itself. Experts in the areas of law, economics as well as in political or international organizations seem to differ in their views of the ML phenomenon. Thus, the definition of the term 'money laundering' is more ambiguous than one would expect. As a result, a variety of definitions have been suggested. In this study we will provide the following definitions as examples: The Financial Action Task Force on Money Laundering (FATF) (FATF chapter III, section 2.3) defines the word ML as 'the processing of ... criminal proceeds to disguise their illegal origin'. A similar definition is the one suggested by The Joint Money Laundering Steering Group, which understands this activity as the 'process whereby criminals attempt to hide and disguise the true origin and ownership of the proceeds of their criminal activities'. According to the United Nations Office on Drugs and Crime (UNODC) and the International Monetary Fund (IMF), money laundering can be described as the process by which a person conceals or disguises the identity or the origin of illegally obtained proceeds so that they appear to have originated 
from legitimate sources' ((IMF, UNODC, 1 December 2005). At the same time, Stessens said that money laundering is a process by which a criminal expects to conceal the criminal origin of assets and 'to ensure that the criminals can "enjoy" their proceeds, by consuming or investing them in the legal economy'. Finally, from an economic point of view, the economist Masciandaro also said that 'money laundering is an autonomous criminal economic activity whose essential function lies in the transformation of liquidity of illicit origin, or potential purchasing power, into actual purchasing power usable for consumption, saving, investment or reinvestment' $[11]$.

\section{Stages of money laundering}

Money laundering is the disguising of funds derived from illicit activity so that they may be used without detection of the illegal activity that produced them. Money laundering involves three stages: placement, layering and integration.

Placement involves physically placing illegally obtained money into the financial system or the retail economy. "Dirty" money is most vulnerable to detection and seizure during placement [19]. Placement is the initial transformation of illicit cash into other assets. At this stage, the source of the cash is still obvious, so money launderers exploit weak AML controls, use deception, or use unknowing, complicit, or corrupt parties to place their cash. Examples include depositing cash in a bank, using cash to purchase assets from unknowing parties or by working with complicit or corrupt parties, paying credit card bills with cash, purchasing foreign currency at a currency exchange, and smuggling cash to weaker AML jurisdictions (www.interactiveservices.com).

Layering: The second stage of money laundering occurs after the ill-gotten funds have gained entrance into the financial system, at which stage, the funds or securities are converted or moved to other institutions, further separating them from their criminal source (www.herald. co.zw). Layering means separating the illegally obtained money from its source through a series of financial transactions that makes it difficult to trace the origin. During the layering phase of money laundering, criminals often take advantage of legitimate financial mechanisms in attempts to hide the source of their funds. A few of the many mechanisms that may be misused during layering are currency exchanges, wire transmitting services, prepaid cards that offer global access to cash via automated teller machines and goods at point of sale, casino services and domestic shell corporations lacking real assets and business activity that are set up to hold and move illicit funds [19].

Integration means converting the illicit funds into a seemingly legitimate form. Integration may include the purchase of businesses, automobiles, real estate and other assets [19]. The third stage of the money laundering process involves the placement of the laundered money back into the economy and financial system in such a way that it appears to be clean and legitimate and is available for use by criminals to buy expensive cars and property or invest in different stocks, unit trusts and money market (www.herald.co.zw). 


\section{The negative effects of money laundering operations}

Money laundering is either within the borders of the state or the money is transferred out of the country. The second case is the most dangerous to the nation's national economy. Phenomenon of money laundering leads to the production of a range of economic and social damages and risks in the community and state. That the damage caused by the transfer of funds to the outside borders of the state, which can be invested in the development to feed the national economy and achieving the economic benefits to the state and citizens. Especially, If the laundered amounts were great with the recurrence of such operations continuously. That risks and economic damages of money laundering are [2, p. 20-21; 28]:

\section{Economic effects}

\section{At the level of the national economy}

Weakening the ability of the authorities to implement economic policies efficiently due to the unreliability of available data and statistics in light of the inability to measure the volume of these operations. Also, the inability to plan the nation's national economy; Weakening the stability of the money market and the foreign exchange market as a result of severe fluctuations in the movement of money, deposits and inward and outward cash flows "financial flows". Also, increase in balance of payments deficit and high external debt. "Depreciation of the exchange rate of national currency". "High interest rates on local currency". "High rates of inflation and declining purchasing power of cash". "Lack of domestic saving rate"; Money laundering creates distortions in the distribution of resources and wealth within the economy; Weakening the economic growth as a result of directing the resources towards unsuccessful investments at the expense of meaningful and real investments. "Economic recession in the state". "Low rates of GDP growth". "Reduction the production capacity (low rate of production capacity)"; The presence of purchasing power that is not the result of real economic activity, which contributes to inflationary pressures in the country's economy and the rise in the general level of prices. "Burning and destruction of the prices"; Lack of real national income due to smuggled money outside the country. "Exhaustion the national economy"; Money laundering contributes to deepening the disparity in the distribution of income among social groups. Also, increase the tax burden. "Failure to achieve justice in the distribution of national income"; Indirect effect "increasing the prices of agricultural products as a result of the increase in land prices in many countries where money is laundered through real estate investment"; The negative impact on government financial resources "low government revenue from taxes" as a result of a decrease or non-increase in the volume of legitimate economic activities that produce taxes.; Doubling of the security efforts and increase the spending.

\section{At the level of the banking system}

The threat of financial and banking stability as a result of the exposure of financial and banking institutions to the risks of loss of confidence and reputation. The possibility of the collapse of stock exchanges that receive illicit money as a result of the sudden sale of securities, which leads to a sharp decline in stock prices. 


\section{Political Implications}

The spread of political and administrative corruption and the exploitation of influence. Damage to the reputation of some countries that are internationally famous for practicing money laundering phenomenon, which leads to the flight of foreign investment; The possibility of directing the money resulting from money laundering to the financing of terrorist organizations, which leads to instability of security "undermine the stability and security"; The possibility of money launderers leaking to some bodies of a special nature, such as People's and Parliamentary Councils, and enjoying political immunity and participation in the development of state legislation, which leads to chaos and corruption and then influencing the political stability of the state. "Penetration in political circles and spreading corruption". Influencing the country's reputation vis-a-vis international aid donors "loans and financial aid", especially for developing countries.

\section{Social Effects}

Aggravating the problem of unemployment; Prevalence of job corruption and purchase of people's support (bribery, embezzlement, etc.). "High rates of economic crimes"; The rise of inferior social groups to the highest social pyramid. Also, "the emergence of new criminal groups in money laundering"; Affecting the fair distribution of tax burdens to society groups; Loosening of social ties. Also, increase moral corruption in society.

Generally, economic crimes contribute to the deterioration of economic, social and political conditions within societies. Economic crimes negatively affect development in its general sense. Economic crimes contribute to creating many tragedies in the economic, social and political fields.

\section{Electronic money and money laundering}

Money plays an important role in the development of commerce, especially electronic ones. It enables its dealers to make deals and settle their value and the person who carries them out is in his/her home or office, and saves the expenses that traditional money requires. Nevertheless, this money has an important risk, which is used illegally for the purpose of committing a money laundering crime, and it turns from a means "to develop trade" into a tool "to commit crime". Electronic money contributed to the spread of the phenomenon of money laundering globally. It is becoming more difficult to control it [4, p. 543].

\section{The growing phenomenon of economic crime, "illegal earning and money laundering" in Libya}

Libyan state as a developing country is suffering from the growing of illegal earning and money laundering phenomenon like other countries. This phenomenon affected negatively the processes of economic development, social and political in Libya. As is well known that the political system in Libya is illegal (from 1969 to 2011). The Gaddafi regime is an illegal political system. This system pursued a deliberate and systematic policy that enables it to stay 
in power for the longest time. The content of that policy is to provide protection for Gaddafi's political system in exchange for turning a blind eye to unlawful gains. Mutual interests between Gaddafi as an illegal ruler and his supporters. Gaddafi was looking for protection and continuity and they were looking for economic gains. Gaddafi's regime contributed to the spread of the phenomenon of illegal earning and money laundering in Libya by adopting a dirty policy that enabled it to remain in power for more than 42 years. Unfortunately, illegal earning activities and money laundering operations have been continuing even after the revolution of February 17, 2011. To build a new Libya and achieve economic, social and political development, the phenomenon of illegal earning and money laundering must be fought. To achieve this must determine the criminal activities associated with illicit gain, methods used in money laundering in Libya and challenges and difficulties that will face the new country of Libya to fight the money laundering and illicit gain. The pre-revolution stage, "February 17, 2011", the political system was one of the main factors that contributed to the spread of the illegal earning phenomenon. As for the continuation of this phenomenon, even after the revolution of February 17, 2011, it is due to the state of political chaos "political conflict, anarchy, violence and organized crime" accompanied by the inability of the security and oversight agencies.

\section{Highlighting the problem}

Economic crime, as a bad phenomenon, is found in almost every country in the world, but at different levels "it is a global phenomenon". Economic crimes negatively affect the economies of countries, and that is why all countries are trying to combat them in every available way. For the Libyan state, it was and still is classified as a focus of economic crime. It is at the forefront of countries that suffer from the growing phenomenon of corruption and the practice of criminal economic activities. What are the reasons that led to this disastrous situation "the aggravation of the phenomenon of economic crime" and how can the Libyan state prevent the continuation of the phenomenon of economic crime? Economic crime in Libya clearly emerged during the Qaddafi era and increased dramatically after the revolution of 17 February 2011. The researcher believes that the political system in Libya "from 1969 to 2011" played a great role in spreading this bad phenomenon and consolidating its roots within Libyan society, and after that, the Libyan revolution came in 2011 to contribute to the aggravation of this abhorrent phenomenon. And in order to study this phenomenon rationally, and find logical explanations and convincing evidences "facts" about it and how to combat it. The researcher will try to find a logical answer to the following questions: What are the main causes, facilitating factors, and prevailing conditions that contributed to the emergence of the phenomenon of economic crime in Libya, "illegal earning and money laundering" during Qaddafi's rule, and what are the reasons that contributed to the exacerbation of this phenomenon after the February 17, 2011 revolution?; What are the criminal activities related to illegal earning that were committed before and after the February 17, 2011 revolution?; What are the difficulties and challenges that the government of the Libyan state will face when it decides to combat the phenomenon of economic crime and radically eliminate it?; What 
are the appropriate methods and necessary measures to combat the phenomenon of economic crime within Libyan society "how to eliminate the phenomenon of economic crime within Libyan society"?

The researcher believes that identifying the causes, facilitating factors, and prevailing conditions that exacerbated the problem of illegal earning and the growing phenomenon of money laundering, and the malicious methods used by criminals, whether with regard to illegal earning or money laundering will contribute to eliminating the phenomenon of economic crime and preventing its occurrence within the Libyan state. Therefore, this study will examine the reasons of the growing of this phenomenon and the difficulties that prevent the fight this phenomenon. In Libya, once the acquisition of illegal money without the presence of criminal evidence can be used to convict (accuse) someone, whereupon, the money will be clean and washed. That money can be used without any problems. Many people earned money by using illegal ways and methods, as a result of lack of criminal evidence. These people have become rich in the Libyan society, and their money is clean from the perspective of law. The researcher believes that the best way to combat the phenomenon of unlawful earning and money laundering in Libya lies in knowing the reasons, motives, facilitating factors and prevailing conditions that led to the emergence and growth of this phenomenon. The optimal way is to prevent economic crime before it happens. That determination the reasons, motives, facilitating factors and prevailing conditions that led to the emergence and growth of illegal gain phenomenon before and after the revolution of February 17, 2011 will help the new Libyan government to fight of money laundering phenomenon and the illegal gain.

"Economic crime is a growing phenomenon within Libyan society that directly affected economic, social and political development. What are its causes and how can it be eliminated"?

\section{Goals of the study}

This study aims to provide an accurate description and clear statement about the phenomenon of economic crime in Libya before and after the February 17, 2011 revolution, that includes the following: (1) To determine the main causes, facilitating factors, and prevailing conditions that contributed to the emergence of the phenomenon of economic crime in Libya, "illegal earning and money laundering" during Qaddafi's rule, as well as, the reasons that contributed to the exacerbation of this phenomenon after the February 17, 2011 revolution; (2) To determine the criminal activities associated with illicit gain in Libya before and after the revolution of February 17, 2011; (3) To determine the methods used in money laundering in Libya before and after the revolution of February 17, 2011; (4) To determine appropriate methods and necessary measures to combat the phenomenon of economic crime within Libyan society how to eliminate the phenomenon of economic crime within the Libyan society; (5) To determine the challenges and difficulties that will face state of new Libya to fight the money laundering and illicit gain. 


\section{Important of the study}

This study is the first that discusses the subject of illegal earning and phenomenon of money laundering explicitly and without any restrictions. Therefore, this study will encourage the researchers in Libya to study the phenomenon of money laundering and the illegal earning. Especially, after the revolution of February 17 and the end of an era of the Revolutionary Committees and the Revolutionary Guards. After the revolution, there will be no any restrictions in the field of scientific research about any phenomenon. Therefore, this study will be considered as the cornerstone of many of the studies in this field in the future. Before the revolution, the study of such phenomena is a red line. researcher's award will be prison or death. The importance of this study lies in determining the necessary measures that must be followed by the new Libyan government to combat the phenomenon of illegal earning and money laundering. Especially, after defining and describing all criminal economic activities and feasible methods of their implementation, as will be presented in this study.

\section{METHODOLOGY OF THE STUDY}

The study will be divided into two parts: the theoretical part; and practical part. The theoretical part included the following: Definition of money laundering phenomenon and illegal earning; Stages of money laundering; Economic and social damages of money laundering and illegal earning; Growing of money laundering phenomenon and illegal earning in Libya. In regard to collect of information and data for this part the researchers will depend on the following sources: (1) By references such as books and journals which interest in the subject of money laundering phenomenon and illegal earning. (2) Archives of crimes in a court of economic crimes; People's Committee for control and Directorate of the public security in Libya. The practical part: The field study included the following: (1) A search tool "Questionnaire". The researcher designed the lists of the questions" the questionnaire" to collect necessary data and information to study the phenomenon of illegal gain and to confirm the integrity and accuracy of the information available to the researcher, the questionnaire was used to collect the views of three communities of people are : Officials and heads of departments, units and offices in the court of economic crimes in Libya; Staff at the Court of Auditors "Court of Accounts", and Directorate of the Public security in the city of Benghazi; Academics in the field of law and economics. In addition to conducting personal interviews with many writers and journalists "honorable" (2) The Statistical study. The researcher used the descriptive statistics method to classify the opinions of the people who were chosen to answer the questions in the questionnaire list. In addition, in many cases, the researcher was dependent on a personal interview style. 


\section{FACTS ABOUT ECONOMIC CRIME IN LIBYA}

Through the data and information obtained from the lists of questionnaire and personal interviews, it can be said that, all opinions were identical and there are no fundamental differences. Through the acquired data and information, a detailed statement and accurate facts can be provided on the following topics: Contribution of the Libyan political system in the growth of the phenomenon of illegal earning and money laundering in Libya; The acquisition of illicit money" money obtained by illegal means" before and after the revolution of February 17, 2011; Who were / are the perpetrators of economic crimes in Libya" before and after the revolution of 17 February 2011"?; Methods Of money laundering in Libya; Combating illegal gains and money laundering in Libya; Types of money laundering in Libya; The major challenges that will face the new Libyan state, if the government wants to combat this phenomenon.

\section{Contribution of the Libyan political system in the growth of the phenomenon of illegal earning and money laundering in Libya}

Before the revolution of February 17, 2011 "During Gaddafi's Era"

Libya is a rich country and a poor people. Colonel Qaddafi took control of the government in 1969 following a military coup, and ruled Libya for four decades until he was ousted in 2011 in a popular uprising supported by armed factions, and supported by NATO. Gaddafi seized the power "rule" and wealth of the Libyan people and contributed to creating a state of poverty and the spread of unemployment within society so that he could control the reins of government in Libya by controlling the food "sustenance" of the Libyans and liquidating his opponents inside and outside Libya.

The dictatorial political system in Libya contributed to the spread of all the bad phenomena within the Libyan state such as illegal earning, financial and administrative corruption and money laundering. The political system in Libya (from 1969 to 2011) is an illegal system. In order for the Qaddafi regime to continue ruling the Libyan state for as long as possible, Gaddafi was turning a blind eye to these crimes. He did not care to address these negative phenomena, as long as the price is to provide protection for his political system. Criminals were mostly members of the Revolutionary Committees Movement and the Revolutionary Guards. Whose only interest was the money. They were above the law. Sanctions were imposed on ordinary people who did not belong to these sects. In the seventies, Gaddafi has established Liaison Office of the revolutionary committees and the Revolutionary Guards in order to protect his revolution and political system. Members of the Revolutionary Committees Organization "Libyan revolutionary committee's movement" and Revolutionary Guards Battalions were Libyan, their mission "task" is to protect of the Qaddafi's regime. They were opportunists, bloody, thieves, they have no morality, collection of money in any way was their only interest. The political system used them as eyes for it in all Libyan organizations and companies of the public sector. The dictatorial regime appointed members of the Revolutionary Committees as 
managers and leaders for public sector institutions in Libya. They were stealing public money of those organizations and they were adept at money laundering. Gaddafi was aware of theft operations, but he was turning a blind eye, in return for providing protection to his political system. The Libyan political system also contributed to strengthening the poverty situation and the spread of unemployment within Libyan society, this led to the growth of the phenomenon of illegal earning and money laundering in Libya. The deterioration of economic conditions for the Libyans helped the spread of all the bad economic phenomena such as corruption, illegal earning and money laundering, etc. During the Qaddafi era, all economic crimes were committed except for the sale of weapons. (In the era of Gaddafi, there is no arms trade in Libya).

It should be noted that, all public factories and companies - that were funded by the Libyan government, that were run by members of the Revolutionary Committees Movement and the Revolutionary Guards failed and disappeared from existence due to the depletion and pillaging of their economic capabilities by this sect.

\section{The close connection among Qaddafi, the members of the revolutionary committee's movement and the revolutionary guards}

The Revolutionary Committees Movement is a political and cultural movement that calls for and promotes the establishment of the Jamahiriya society, the authority of the people (direct democracy) as presented by the Third Universal Theory of The Green Book (RCM, n.d.). In managing the Libyan state affairs, Qadhafi relied on members of the Revolutionary Committees Movement and the Revolutionary Guards. All leadership positions in the Libyan state were managed by this group of people. Their slogan was ... the member of the Revolutionary Committee and the Revolutionary Guards is "the first to sacrifice and the last to benefit." The opposite was the truth. Some of them were involved in the operations to liquidate Gaddafi's opponents, the price given to them by Gaddafi was absolute freedom to do anything. The relationship among Qaddafi and members of the Revolutionary Committees movement and the Revolutionary Guards is a relationship of mutual interests" mutually beneficial relations." The first party was asking for protection and to stay as long as possible and the other parties were seeking to achieve greater local economic benefits at any cost. As a result, economic crime spread in Libya during the Qaddafi era. In fact, this group of people can be divided into two parts: Part was believed in the third world theory and the green book (the country's Jamahiriya system of "rule by the people".). These people were interested in promoting the ideas of Gaddafi. They were few, and they are honorable. The other part was only interested in achieving economic gains at any cost.

\section{After the revolution of February 17, 2011 "after the end of Gaddafi's rule"}

When Gaddafi knew that his end was approaching-as a punishment for the Libyan people, he released the criminal prisoners, as well as armories, for the Libyans to live in a state of extreme violence. After the end of Gaddafi's rule, the Libyan state entered a cycle of violence and political chaos accompanied by all kinds of crimes, including economic crimes. Due to the political conflict, the lack of an effective role for security institutions, the emergence of 
terrorist organizations in Libya, and the politicians' preoccupation with their political struggle, economic crime has grown frighteningly. In fact, after the revolution there was no government in the true sense of the word. Control in Libya was and still is for armed militias. After the revolution, conditions worsened in Libya, and this deterioration led to an alarming increase in the crime rate. Politicians and militia leaders have plundered Libyan money through financial corruption activities. This was not hidden. The United Nations and countries interested in Libyan affairs were aware of these economic crimes, especially the crime of financial corruption that exceeded all perceptions. Ghassan Salama, the UN envoy, head of the Support Mission in Libya "Special Representative of the Secretary-General for Libya Ghassan Salamй as the head of the UN Support Mission in Libya, UNSMIL", said that "what is happening in Libya is not corruption, but rather is systematic looting of state finances", noting that there are "international parties involved in the continuous plundering of Libyan money" [6]. From 2011 to 2020 there have been no initiatives to address the crime phenomenon in general. Economic and noneconomic crimes were and are still continuing in Libya. This is confirmed by the report of the United Nations Secretary-General at the beginning of the year 2020. Report of The SecretaryGeneral Antynio Guterres on The United Nations Support Mission in Libya - 15 January 2020. In general, this report contained an accurate description of the catastrophic situation in Libya, the researcher chose the following paragraphs to indicate the United Nations' concern about the phenomenon of economic crime in Libya. "Situation in the western region, armed groups in Tripoli continue to threaten individuals who impede their access to resources". Eastern Libya has experienced a deterioration in law and order, including numerous cases of crimes and intimidation, reportedly by elements affiliated with the Libyan National Army, mostly in Benghazi. Benghazi has become a hub for illicit economic activities, including the sale of drugs and arms. During the reporting period, the police arrested several individuals involved in drug dealing and trafficking in arms" [31].

\section{The acquisition of illicit money "money obtained by illegal means" before the revolution of February 17, 2011 \\ During Gaddafi's Era}

The following economic crimes were taken from the files and records of economic crimes court, police stations, and The General People's Committee for Popular Control and Inspection Authority in Libya. Those crimes are: (1) Theft and misappropriation of funds of public sector institutions; (2) Manufacture and sale of local wines; (3) The drug trade; (4) Smuggling of subsidized goods (Goods sold to citizens at subsidized prices from the State) to neighboring countries; (5) Currency trading in the black market and counterfeit-currency trading; (6) Illegal gains from illegal immigration deals to Europe; (7) Fishing by hand grenades (manufactured locally); (8) Deforestation "cutting down trees" in order to manufacture coal; (9) Sale of infringing goods to the specifications (manipulation of the expiry date and product quality); (10) Steal cars and sell them as used spare parts; (11) Steal the animals from farms; (12) Sale of goods without a license in the streets. (13) Tax evasion; (14) Bribery and corruption in all 
their forms in public sector organizations; (15) Smuggling workers and fugitives from justice in their countries or for other reasons from and to neighboring countries; (16) Possession of more than one employment contract in more than in more than one public institution "One person has a job in more than one public institution"; (17) Illegal commissions in suspicious external and internal deals; (18) Bribes paid to the security men at checkpoints on roads, airports and seaports by travelers; (19) Unlicensed trade "luggage trade"/ street vendors; (20) Tax evasion; (21) Practice of astrology, divination, magic, and sorcery; (22) Trafficking in women and exploitation of women in prostitution. In the era of Gaddafi, there is no arms trade in Libya.

\section{The Acquisition of illicit money "money obtained by illegal means" after the revolution of February 17, 2011}

\section{After the end of Gaddafi's rule}

Gaddafi, before his death, opened the doors of prisons and the armories, As punishment for the Libyan people. There were more than 20,000 dangerous criminals armed with weapons. some of them died in wars and others are still alive. They move around in the middle of the streets freely. Until this moment "February 2020" they are doing what they want unchecked. Gaddafi's retaliatory response to the Libyan people has contributed to multiplying the crime rate hundreds of times in Libya.

In fact, all the crimes mentioned above have continued after the revolution of February 17 , 2011 with a higher rate than the previous time as a result of the loss of security in the country. It must be pointed to the emergence of new crimes were not present in previous such as crimes of armed robbery and arms trade. Theft of assets of Libyan and foreign companies during the war period. The establishment of armed militias that obtain money by blackmailing the government. The spread of the arms trade phenomenon. Theft of antiquities from historical sites, museums, antique businesses and galleries. Robbery of state lands and sell them to citizens as residential lands. Due to the high price of the US dollar on the black market in Libya, Libyan businessmen and traders obtain the subsidized dollar from the Central Bank of Libya under the pretext of importing goods and then they re-sell it on the black market. Selling crude oil outside the OPEC system "illegal sale at prices lower than OPEC prices". Kidnapping and extortion. During the war in 2011, Gaddafi paid large sums to the Libyans for fighting with him, he used them as mercenary in the Libyan war, the mercenaries were from the western region, that sums are illegal from the perspective of law, mercenaries washed that money through the purchase of houses and farms in the eastern region in Libya, there no one will recognize them. As well as, there are large amounts of money, arms and gold fled to Egypt, Chad, Mali, Algeria, Sudan and Niger. As well as, increase the volume of transactions of illegal immigration After the revolution of February 17, 2011. Seizure of property of members of the Revolutionary Committees Movement and the Revolutionary Guards, as well as property of opponents of any regulation "political movement" that came after the February 2011 revolution, as Qaddafi did with his opponents during his rule in Libya. Due to the high price of copper in international markets, criminals stole the power transmission cables of the General Electricity Company 
"GECOL" and sold them in neighboring countries. Sale of subsidized goods in unsupported goods packages "Cardboard boxes and plastic bags" to take advantage of the price difference. Hiding the basic commodities from the Libyan market in order to raise their prices in the future.

\section{Who were / are the perpetrators of economic crimes in Libya "before and after the revolution of 17 February 2011"? \\ Before the revolution of February 17, 2011}

For the financial and administrative corruption crimes, they were committed by leaders and officials in public sector institutions who are mostly from the Revolutionary Committees Movement and the Revolutionary Guards. As for the crimes of theft, drug and alcohol trafficking, they were committed by "ex-convicts" criminals. Other economic crimes were committed by the poor, the unemployed persons and some corrupt businessmen.

\section{After the revolution of February 17, 2011}

After the revolution, weapons spread inside the Libyan territories. This disaster has contributed to the emergence of organized crime and criminal gangs. The crimes of theft, drug and alcohol trafficking, and arms trade they were committed by "ex-convicts" criminals. Blackmailing and threatening the government in order to obtain money and other economic benefits were committed by armed militia leaders. Kidnapping and extortion crimes were committed by criminal gangs. For the financial and administrative corruption crimes, they were committed by some politicians, leaders in the public sector institutions and corrupt businessmen. Other economic crimes "which does not include the sale of weapons, drugs and alcohol" were committed by the poor and the unemployed persons.

\section{Methods of money laundering in Libya}

Before and after the February 17, 2011 revolution, for the non-political and non-leadership figures "not prominent figures in the Libyan society", they do not need to launder illegal money. As for well-known political figures, as well as prominent leadership figures, they launder illegal money as a precaution. Before the February 17, 2011 revolution, some prominent members of the Revolutionary Committees and Revolutionary Guards were laundering illegal money to avoid embarrassment, criticism, and blame from their leader "Gaddafi" and not to receive punishment.

In Libya, once the illegal money is acquired (illegally acquired funds) without the presence of criminal evidence can be used to convict or accuse someone, whereupon, the money will be clean and washed, no need for the process of washing, therefore can deposit the money in accounts in Libyan banks without any problems. But Members of the Revolutionary Committees and the Revolutionary Guards, and managers of public sector institutions were used two ways are: Depositing illegal money in personal accounts in European, Asian and Arabic banks or depositing illegal money in accounts of their relatives in Libyan banks or purchase of immovables (real estate "buildings, lands and farms") that are registered in the names of their relatives to keep them away from the suspicions. As for the others, they often 
deposit the money in their personal accounts in Libyan banks without any problems. As well as, they can buy immovables (real estate "buildings, lands and farms") that are directly registered with their names to prove and document the property without any difficulty. Also, Purchase of immovables in the Republic of Egypt, as the Egyptian law allows foreigners to purchase the real estate.

In general, as is common, there is no legal accountability regarding possession of unlawful money "after the completion of the implementation of the economic crime", but criminals are always cautious and try to conceal that money and its source as a precaution. In general, before and after the February 17, 2011 revolution, officials, leaders, politicians and prominent personalities in Libya resort to laundering illegal money to avoid gossip "people's words: blame, reproach and contempt". Referring to them as corrupt people can drive them away from their leadership positions. Especially people who are not members of the Revolutionary Committees Movement and the Revolutionary Guards. The eyes are always open for them to monitor their faults and violations. In order to maintain their leadership positions, they must be vigilant. That is why they resort to money laundering. In Libya, we have not heard that an official has been imprisoned for his illegal money. During the Qaddafi era, we used to hear that a leader was removed from his current leadership position to assume another leadership position. Gaddafi was moving them from their leadership positions to other leadership positions instead of imprisonment.

\section{Fighting of money laundering in Libya}

The legislative body in Libya (Secretariat of General People's Congress) issued Law No. (2) of 1979 on economic crimes and Law No. 2 of 2005 on the anti- money laundering. Before the revolution of 17 February 2011 Members of the Revolutionary Committees and the Revolutionary Guards are always above the law so there is no strict fighting of the phenomenon of money laundering and the illegal gain. Economic gains from illegal activities are the price paid by the Gaddafi regime to stay in power. The crimes of the illegal gain implemented by people who are not Members of the Revolutionary Committees, or Revolutionary Guards, if discovered by police, criminals will be subjected to sanctions, especially the sale of drugs and alcohol.

\section{Types of money laundering in Libya}

Internal laundering: Once the acquisition of illegal money (illegally acquired funds) or when the illegal money is acquired without the presence of criminal evidence can be used to convict or accuse someone, whereupon, the money will be clean and washed, there will be no need for the process of washing. This feature is for funds being illegally acquired by unknown persons "not prominent" belonging to the Revolutionary Committees Movement and the Revolutionary Guards and managers of public sector institutions, especially unknown individuals and other people who are not members of the Revolutionary Committees and the Revolutionary Guards, that money can be used in the procurement process or the investment 
or depositing in the banks without any problem. As a precaution, when the sums are large, these corrupt people register property ownership in the names of their relatives to hide the illegal money.

External laundering: Members of the Revolutionary Committees and the Revolutionary Guards, and managers of public sector institutions, especially well-known personalities transfer "smuggle" the funds to the Arab, European and Asian countries and invest them in those countries. They will be as foreign investors from the perspective of those countries. Or buy real estates in neighboring countries and some other countries that permit this. This method continued even after the revolution.

\section{The factors and prevailing conditions that helped the emergence and growth of the phenomenon of economic crime in Libya}

There are many factors and circumstances that contributed to the spread of the phenomenon of economic crime in Libya are:

- Ignorance, poverty, and unemployment within Libyan society contributed directly to the emergence of the phenomenon of economic crime in Libya;

- The poor economic conditions in which most Libyans live due to poor and insufficient salaries contributed directly to the emergence of the phenomenon of economic crime, especially financial corruption crimes in public sector institutions such as "bribery and embezzlement";

- Ease of obtaining forged documents "forged bills" to hide "preventing the discovery" crimes of financial corruption in public sector institutions;

- Supported goods "subsidized goods" in Libya that are sold to Libyan citizens at cheap prices such as "corn oil, sugar, flour, tea, milk, rice and fuel". The availability of these commodities contributed to an increase in smuggling trade to neighboring countries. Supported goods can be sold in neighboring countries and make huge gains;

- The Libyan state has geographical borders with the vast expanse with many neighboring countries, those land borders that link Libya with the lands of many neighboring countries. These limits are not always well monitored by the relevant authorities. Those borders need great potential, and serious regional and international cooperation from all neighboring countries and countries concerned with illegal immigration in order to tighten control over these borders and prevent their use in illegal trade and illegal immigration. Difficulty controlling the vast geographical borders was exploited by criminals in their illicit trade such as smuggling of cigarettes, alcohol, drugs, subsidized goods, fuel and illegal immigrants who migrate by sea to Europe;

- The lack of strict control over the land, air and sea customs ports. The absence of strict control of the maritime traffic "fishing boats" to prevent the smuggling of fuel to Malta and Tunisia, as well as illegal immigrants to Europe;

- The uncontrolled spread of weapons in Libya after the revolution of February 17, 2011 contributed to the formation of armed gangs and militias, and the emergence of what is 
known as organized crime. Also, exporting weapons to neighboring countries;

- Anti-economic crime laws are not fully activated. Before and after the revolution, most of the leaders in Libya are corrupt people. They are above the law, and therefore laws cannot be imposed and applied to combat economic crime in a fair manner. Any serious attempt to combat the phenomenon of economic crime in Libya will fail. Laws in this area are imposed only to the poor and vulnerable. As well as, Libyan prisons are not qualified to improve the behavior of criminals for their rehabilitation and reintegration into society, this situation helped the spread of crimes, especially crimes of illegal gain;

- Banks and Departments of Registration of Real Estate "authorities responsible for the registration of real estate ownership" have no role in the process of combating money laundering. There is no coordination or cooperation among the security agencies, banks, and real estate registration bodies in Libya with the aim of combating the phenomenon of money laundering;

- There is no cooperation between the Libyan authorities and the authorities in the neighboring countries regarding tracking the movement of smuggled funds from Libya to these countries to verify the legitimacy of these funds. There is no regional cooperation to combat money laundering. The economies of the neighboring countries benefited a lot from the smuggled money from Libya. This may be a reason to justify the lack of regional and international cooperation to combat this phenomenon;

- The absence of effective and influential consumer protection organizations and environmental protection organizations in Libya that can exercise their role in pressuring the government to meet their demands regarding consumer protection from the negative effects of illegal trade. As well as protecting the Libyan environment from harm caused by criminals, "protecting the marine environment from fishing with explosives and poisons- and cutting down forest trees to make charcoal";

- Many employees of the security agencies are corrupt police and security officers who have contributed to the spread of economic crimes, such as drug and alcohol trafficking, etc;

- Libya has a beach with a length of $1955 \mathrm{~km}$. This geographical advantage is a real obstacle to monitor smuggling operations along the Libyan marine beaches.;

- The Libyan citizen has the freedom to own more than one personal current bank account in more than one bank. These accounts are used to hide illegal funds by distributing them into small shares on these accounts;

- There are minefields since World War II on the border between Libya and Egypt. Criminal fishers use mines in these fields to make grenades for fishing.

\section{The biggest challenge that will face the new Libyan government}

After the revolution of February 17, 2011, Almost all Libyans have weapons, more than 25 million pieces of weapons are in the homes of the Libyans and their cars. This problem will represent the greatest challenge that will face the new Libyan government when trying to fight of crimes of illegal gain and money laundering. 


\section{RESULTS}

This study relied on analyzing and classifying data and information recorded in the records of the judicial and security authorities in Libya, Transparency International reports, and the reports of the United Nations Mission in Libya. As well as, analyzing, studying and evaluating the lived reality in Libya over the period under study. The most important results of this study are represented in the following two facts: 1) The Gaddafi regime (the dictatorial political system) contributed to the spread of economic crime, including financial and administrative corruption, in the public sector institutions in Libya. Poverty, the dictatorial political system and the weak performance of the security and oversight bodies contribute directly to the spread of economic crimes in any country. During Gaddafi's rule in Libya, the Libyan state was classified as a failed state plagued by corruption; 2) After the collapse of dictatorship in Libya, "the end of Gaddafi's rule" the rate of economic crime (in all its types and forms) has increased dramatically, foretelling a catastrophic situation. It should also be noted that after the February 2011 revolution, other types of economic crimes appeared that did not exist during the Gaddafi era, such as human trade, illegal immigration and arms trade.

\section{RECOMMENDATIONS}

\section{First: regarding fighting the phenomenon of illegal earning}

(1) The need to find serious cooperation between neighboring countries and the Libyan authorities in the field of guarding and controlling the Libyan borders" strengthening border surveillance," to prevent the smuggling of goods, fuel, drugs and illegal immigration" the necessity of signing binding agreements with neighboring countries to protect the common borders"; (2) Improving the economic conditions of the sons of Libyan people to prevent the phenomenon of the illegal gain and money laundering; (3) The need to confiscate weapons from the hands of the sons of Libyan people, so that the security forces (police and security men) can fight the phenomenon of the illegal earning and money laundering; (4) Removal of subsidies on basic goods, fuel and medicines to prevent the smuggling of subsidized goods, fuel and medicine to neighboring countries. Changing the economic policy regarding subsidized goods from direct to indirect subsidies" from support in the price of goods to support in increasing the purchasing power of Libyans"; (5) Increase the salaries of policemen and material and moral incentives to ensure their loyalty during fighting operations of the illegal earning; (6) Not allowing more than one personal current bank account per person" as a precautionary measure to combat money laundering through bank accounts"; (7) The necessity of activating the role of the courts of economic crimes in Libya; (8) The necessity of the strict control on the Libyan ports and airports to prevent the smuggling of alcohol, drugs and money; (9) The need to develop Libyan law in the field of fighting of illegal earning and money laundering, as 
well as the development of Libyan prisons to be appropriate for the rehabilitation of criminals; (10) The need to find radical solutions to address the phenomenon of unemployment in Libya; (11) The need to remove corrupt businessmen from engaging in economic activity in Libya, to exclude all corrupt leaders and officials, and to cleanse public sector institutions from them.

\section{Second: regarding fighting the phenomenon of money laundering}

The Libyan authorities should establish the Financial Intelligence Department to contribute to combating the phenomenon of money laundering, with the need to find coordination and a working mechanism among the Financial Intelligence Department, the banks, the real estate registry offices "Real Property Register" regarding the exchange of information about the movement of ownership, deposits and cash withdrawals from banks. In addition to the need to find coordination and a working mechanism between the Financial Intelligence Department in Libya and the authorities in neighboring countries.

\section{CONCLUSIONS}

There is no doubt that the illegal "dictatorial" political system in Libya was a major cause of the emergence and growth of the phenomenon of illegal gain, "economic crime". That system - which contributed to the spread of bad economic phenomena such as poverty and unemployment within society despite the fact that Libya is a rich country, is the first and last responsible for destroying the moral values of most of the Libyan people. When the illegal political system was overthrown in Libya in 2011, the rate of economic crime increased dramatically as a result of the emergence of overwhelming chaos. This chaos, which was and still is accompanied by a state of fierce political conflict between the blocs and political parties.

\section{In general, a group of facts about the phenomenon of economic crime in Libya can be drawn as follows:}

Dictatorial Political system in Libya was one of the difficulties that prevented the process of money laundering fighting and the illegal gain. Dictatorial Political system in Libya was turning a blind eye to criminal activities associated with the illegal gain and money laundering which was executed by Members of the Revolutionary Committees and the Revolutionary Guards in return for (In exchange for) providing protection to this system and to stay in power as long as possible. The spread of poverty and unemployment among the sons of Libyan people contributed to the growing phenomenon of the illegal gain and money laundering. Lack of effective oversight bodies and security services contributed to the growing phenomenon of the illegal gain and money laundering.

After the revolution of February 17, 2011, there is a noticeable increase in the rate of economic crime caused by the collapse of the Libyan state and its institutions, political chaos, "political instability", lack of effective oversight bodies and security services, the spread of weapons in people's hands, the emergence of armed gangs, militias, and organized crime. 
There are some difficulties that will face the new Libyan government to fight of money laundering phenomenon and the illegal gain. The new Libyan government will face great challenges, that challenges are the spread of weapons and the vast geographical boundaries when fighting of phenomenon of the illegal gain and money laundering; Proliferation of arms in the hands of the people is the most important difficulty that will prevent the fight against money laundering phenomenon and the illegal earnings; The lack of possibilities to guard the geographical boundaries of Libya to prevent illegal immigration and smuggling of goods and drugs.

\section{REFERENCES}

1. Abdullah Ezzat Barakat (2006). Phenomenon of money laundering and its economic and social effects at the global level. Journal of the economies of North Africa, 4, 215-232.

2. Al-Khatib, Sameer (2007). Combating money laundering operations. munsha'at almaerif balaskndry.

3. Alex Ferguson (n.d.). Money Laundering. Alex Ferguson - Legal Adviser, Caribbean Criminal Asset Recovery Programme. Retrieved from: www.cicad.oas.org.

4. Al-Zalami, Bassam Ahmed (2010). The role of electronic money in money laundering operations. Damascus University. Journal for Economic and Legal Sciences, 26 (1), 548559.

5. Archives of the economic crimes courts in Benghazi and Tripoli in Libya, People's Committee for control and Security Directorate of Benghazi and Tripoli.

6. Bawwabat Alwasat "Swt Libia Alduwalii" (2017). Special Representative of the SecretaryGeneral for Libya Ghassan Salamй as the head of the UN Support Mission in Libya, UNSMIL, "said that" what is happening in Libya is not corruption, but rather is systematic looting of state finances. Retrieved from: http://alwasat.ly/news/Libya/153209

7. Cambridge Law Journal (C.L.J.) (2008). Vol. 67, Part 3, November 2008, 636. A special intergovernmental body set up by the G-7 Summit in 1989 to combat ML. For further information about the FATF see chapter III, section 2.3. Available at: http://www.fatfgafi.org (accessed 8 November 2019).

8. Complyadvantage (n.d.). Financial Crime. Retrieved from: https://complyadvantage. com/knowledgebase/financial-crime/

9. Christopher K. Lamont (2016) Contested Governance: Understanding Justice Interventions in Post-Qadhafi Libya. Journal of Intervention and Statebuilding, 10 (3), 382-399, DOI: 10.1080/17502977.2016.1199479

10. Cruz A. Echevarrнa \& Javier Garcha-Enrrquez (2019). The Economic Consequences of the Libyan Spring: A Synthetic Control Analysis. Defence and Peace Economics, 30 (5), 592-608, DOI: 10.1080/10242694.2018.1446241

11. D. Masciandaro (2007). 'Black Finance: The Economics of Money Laundering' (Edward Elgar Publishing Ltd., Cheltenham, UK 2007) 2.

12. Europol (n.d.). Economic crime. Retrieved from: https://www.europol.europa.eu/crimeareas-and-trends/crime-areas/economic-crime. 
13.FATF, Money Laundering FAQ (2009). What is money laundering? Retrieved from: http:// www.fatf-gafi.org.

14. Federal Supplement (1982). vol. 551, South District of Florida (1982), 314; cited in Nicholas Ryder, "The Financial Services Authority and Money Laundering. A game of Cat and Mouse".

15. Heba Shams (2004). 'Legal globalization: Money Laundering Law and Other Cases' (Sir Joseph Gold Memorials Series, Vol. 5, The British Institute of International and Comparative Law, London 2004) 2-3. Retrieved from: https://searchworks.stanford.edu/ view/5725342.

16. Huntington, S. P. (1968). Political Order in Changing Societies, New Heaven: Yale University Press.

17. Irene Costantini (2016) Conflict dynamics in post-2011 Libya: a political economy perspective. Conflict, Security \& Development, 16 (5), 405-422, DOI: 10.1080/14678802.2016.1212534

18. Joint Money Laundering Steering Group (2008). Prevention of Money Laundering / Combating the Financing of Terrorism: Guidance for the UK Financial Sector Part I (London, 2006). Cited in N. Ryder, 'The Financial Services Authority and Money Laundering. A game of Cat and Mouse', Cambridge Law Journal (C.L.J.) (2008), 67, Part 3, 636 .

19. Laura Bruce (2006). The stages of money laundering. Retrieved from: http://www. bankrate.com/ brm/news/bank/20060628c1.asp.

20. Law No. 2 (2005) on the anti-money laundering, Secretariat of General People's Congress. (Libya).

21. Law No. (2) of 1979 on economic crimes, The General Secretariat of the General People's Congress.

22. Leff, N.H. (1964). Economic Development through Bureaucratic Corruption. American Behavioral Scientist, 8 (3), 8-14.

23. Merriam-Webster (n.d.). Organized Crime. Retrieved from https://www.merriamwebster.com/dictionary/organized\%20crime.

24. Munawar Meliti (2018). How corruption in Libya turned into a culture? bawwabat 'iifriqia al'iikhbaria.14 June, 2018. Retrieved from https://www.afrigatenews.net/article/.

25. RCM (The Revolutionary Committees Movement). Retrieved from: https://rcmlibya. Wordpress.com/about-the-rcm/our-goals/.

26. Reverso Dictionary (n.d.). illicit gains meaning. Retrieved from: https://dictionary. reverso.net/english-cobuild/illicit+gains.

27. Tariq Kazim Ajil (2007). The crime of money laundering. Magazine of integrity and transparency for Research and Studies, 31-56. Retrieved from: http://www.nazahaiq/ magazen_nazah_m.asp.

28. Saleh Al -Saad (n.d.). Damage and risk of money laundering. Retrieved from http:// sciencesjuridiques.ahlamontada .net/t628-topic.

29. Sriyalatha, Mallika Appuhamilage Kumudini (2019). The Impact of Corruption on Economic Growth: A Case Study of South Asian Countries. Journal of Business Management and Economic Research (JOBMER), 3 (10), 35-47.

30. United Nations (2005). Office for Drug Control and Crime Prevention and International 
Monetary Fund, 'Model Legislative on Money Laundering and Terrorism Financing (for civil law legal systems)' (Report) (IMF, UNODC, 1 December 2005) 1.

31. UN (2020). Report of The Secretary-General Antynio Guterres on the United Nations Support Mission in Libya - 15 January 2020. Retrieved from: https://unsmil.unmissions. org/sites/default/files/sg_report_to_sc_15_january_2020_eng.pdf.

32. Youssef Mohammad Sawani (2018). Public Administration in Libya: Continuity and Change. International Journal of Public Administration, 41 (10), 807-819, DOI: 10.1080/01900692.2017.1387146

\section{INFORMATION ABOUT THE AUTHOR}

Younis A. Battal Saleh (Libya, Benghazi) - Lecturer and researcher. Training Department in HRM of General Electricity Company "GECOL". E- Mail: younisbattal1968@yahoo.com. ORCID ID: 0000-0002-4209-3132 